\title{
Prevalence of anemia among female medical students and its correlation with menstrual abnormalities and nutritional habits
}

\author{
Bhuvaneshwari Kannan $^{1 *}$, Erli Amel Ivan²
}

\begin{abstract}
${ }^{1}$ Department of Obstetrics and Gynecology, ${ }^{2}$ Department of Pathology, Sri Manakula Vinayagar Medical College and Hospital, Kalitheerthalkuppam, Puducherry, India
\end{abstract}

Received: 19 April 2017

Accepted: 24 April 2017

\section{*Correspondence:}

Dr. Bhuvaneshwari Kannan,

E-mail: zoomtobhuvan@gmail.com

Copyright: ( $\odot$ the author(s), publisher and licensee Medip Academy. This is an open-access article distributed under the terms of the Creative Commons Attribution Non-Commercial License, which permits unrestricted non-commercial use, distribution, and reproduction in any medium, provided the original work is properly cited.

\begin{abstract}
Background: The prevalence of iron deficiency anemia, which is the commonest cause for anemia, is $52 \%$ in Indian women aged 15 to 49 years, as per WHO statistics. Health consequences of anemia include reduced immunity, increased morbidity and impaired cognitive performance.

Methods: The study participants were requested to fill in a pretested self-administered questionnaire. Under aseptic precaution $2 \mathrm{ml}$ of venous blood sample was collected in EDTA vacuum tubes and tested for $\mathrm{Hb} \%, \mathrm{PCV}, \mathrm{RBC}$ indices using automated analyzer - Pentra ES 60 and peripheral smear study was done by the pathologist.

Results: Anemia was present in $43 \%$ of the study population with $37 \%$ having mild anemia. Hematocrit was less than normal in $36.2 \%$ of the study population with $32.2 \%$ showing hypochromia and $21.5 \%$ showing microcytosis, thus confirming iron deficiency status. Peripheral smear study revealed microcytic hypochromic blood picture in $26 \%$, normocytic hypochromic in 38\% and normocytic normochromic in $32 \%$ of the anemic subjects. Menorrhagia was present in $14 \%$ of the anemic students whereas $14.1 \%$ of the non-anemic subjects had oligomenorrhoea.

Conclusions: Frequent screening of the students for the presence of anemia and regular health checkups is a must in all school and university students.
\end{abstract}

Keywords: Adolescent anemia, Iron deficiency anemia, Medical college study, Student anemia

\section{INTRODUCTION}

Anemia, which is the most prevalent nutritional problem worldwide, occurs more commonly in young children, pregnant women and women of child bearing age. ${ }^{1}$ The prevalence of iron deficiency anemia, which is the commonest cause for anemia, is $52 \%$ in Indian women aged 15 to 49 years, as per WHO statistics. ${ }^{2}$ Health consequences of anemia include reduced immunity, increased morbidity and impaired cognitive performance..$^{2-4}$

Accelerated growth, hormonal changes, onset of menstruation and malnutrition due to changes in the food habits are the main causes of iron deficiency anemia in adolescent girls. ${ }^{5,6}$ Adolescent period is crucial due to transition from childhood to adulthood and it is the most appropriate time, to intervene any health problem. ${ }^{7}$ Women with even mild anemia experience fatigue and reduced work capacity. ${ }^{8}$

Poor eating habits are a major public health concern among university students. Meal skipping, eating away from home, snacking and fast food consumption predispose them to dietary deficiencies. ${ }^{9} 10$ Also, chronic blood loss due to changes in menstrual pattern, worm infestation etc., further increase their chance of being anemic. Students who study medicine, also follow the same pattern, inspite of them having better knowledge about health and better access to health care facilities. 
Hence, the present study was conducted in Sri Manakula Vinayagar Medical College and Hospital, to assess the prevalence of anemia among its female students and its correlates. It also provides an opportunity, to intervene at a point in life, before the potential problems become serious later in life.

\section{METHODS}

This cross-sectional study was conducted among female under graduates of Sri Manakula Vinayagar Medical College and Hospital between September 2015 and January 2017.Based on the prevalence of anemia of $24 \%$ in the referral study, with $95 \%$ confidence interval and absolute precision of $8 \%$, the sample size was calculated to be149, using Epi info version 3.5.1. ${ }^{11}$ Institutional ethics committee permission was obtained.

After taking informed consent, the willing subjects were requested to fill in a pretested self-administered questionnaire. It contained socio-demographic data, symptoms of anemia, menstrual history, dietary habits, history of worm infestation and chronic blood loss.

All the subjects were examined for pallor and anthropometric data were measured. Under strict aseptic precaution $2 \mathrm{ml}$ of venous blood sample was collected in EDTA vacuum tubes and tested for $\mathrm{Hb} \%$, PCV and RBC indices using automated analyzer-Pentra ES 60.

Peripheral smear study was done by the pathologist, thus confirming the type of anemia and the results were conveyed to the subjects. Those found to be anemic were further evaluated by physician and treated. Students with menstrual abnormalities were treated in gynaecology department. The cut-off value for determination of anemia was haemoglobin value $<12 \mathrm{gm} / \mathrm{dl}$ and severity of anemia was based on WHO classification. ${ }^{12}$

BMI was graded based on WHO classification for Asian population. ${ }^{13}$ Of the red cell indices, MCV <80 fl was taken as microcytic, $\mathrm{MCV}>96 \mathrm{fl}$ as macrocytic and $\mathrm{MCH}$ $<27 \mathrm{pg}$ as hypochromic anemia.

The responses were collected and analysed using freely available software Epi Info version 3.5.1. Frequencies and percentages were calculated and Chi-square was applied to find out the statistical significance. $\mathrm{P}$ value $<0.05$ was considered significant.

\section{RESULTS}

The age of the study participants ranged from 18 to 25 years. All the participants belonged to upper middle class or upper class by Modified Kuppuswamy's scale. ${ }^{14}$

The mean $\mathrm{Hb} \%$ of the study population was $11.9 \mathrm{gm} / \mathrm{dl}$. Anemia was present in $43 \%$ of the study population with $37 \%$ having mild anemia (Table 1 ).
Table 1: Prevalence of anemia among the study participants.

\begin{tabular}{|lll|}
\hline $\begin{array}{l}\text { Severity of anemia } \\
\text { based on haemoglobin } \\
(\mathrm{g} / \mathrm{dl})\end{array}$ & $\begin{array}{l}\text { No. of } \\
\text { subjects } \\
(\mathrm{n}=149)\end{array}$ & Percentage \\
\hline Mild $(11-11.9)$ & 55 & 37 \\
\hline Moderate $(8-10.9)$ & 6 & 4 \\
\hline Severe $(<8)$ & 3 & 2 \\
\hline Non-anemic $(>12)$ & 85 & 57 \\
\hline
\end{tabular}

Hematocrit was less than normal in $36.2 \%$ of the study population. On observing the red cell indices abnormality, $32.2 \%$ had hypochromia and $21.5 \%$ had microcytosis thus confirming iron deficiency status (Table 2).

Table 2: Abnormal red cell indices in the anemic subjects.

\begin{tabular}{|lll|}
\hline $\begin{array}{l}\text { Abnormal red cell } \\
\text { indices }\end{array}$ & $\begin{array}{l}\text { Number of } \\
\text { subjects }\end{array}$ & Percentage \\
\hline Pcv $<38 \%$ & 54 & 36.2 \\
\hline Mcv $<80 f l$ & 32 & 21.5 \\
\hline Mch $<27 \mathrm{pg}$ & 48 & 32.2 \\
\hline Mchc $<32 \%$ & 24 & 16.1 \\
\hline
\end{tabular}

Menorrhagia was present in $14 \%$ of the anemic students whereas $14.1 \%$ of the non-anemic subjects had oligomenorrhoea (Table 3 ).

Table 3: Pattern of the menstrual cycle in the study subjects.

\begin{tabular}{|c|c|c|c|}
\hline $\begin{array}{l}\text { Menstrual } \\
\text { pattern }\end{array}$ & $\begin{array}{l}\text { Anemic } \\
\text { subjects } \\
(n=64)\end{array}$ & $\begin{array}{l}\text { Non-anemic } \\
\text { subjects } \\
(\mathrm{n}=\mathbf{8 5})\end{array}$ & \\
\hline Menorrhagia & $9(14 \%)$ & $3(3.5 \%)$ & \multirow{6}{*}{$\begin{array}{l}\mathrm{p}- \\
\text { value } \\
0.094\end{array}$} \\
\hline Oligomenorrhoea & $4(6.3 \%)$ & $12(14.1 \%)$ & \\
\hline Polymenorrhoea & none & $1(1.2 \%)$ & \\
\hline Metrorhagia & none & $1(1.2 \%)$ & \\
\hline Hypomenorrhoea & none & $1(1.2 \%)$ & \\
\hline Normal cycle & $51(79.7 \%)$ & $67(78.8 \%)$ & \\
\hline
\end{tabular}

Both the study groups complained of some symptoms of anemia irrespective of their haemoglobin status, with $21.5 \%$ having more than 4 symptoms. There is no statistically significant difference between both the groups, with respect to skipping of breakfast, type of diet, frequency of fried food and fruits and vegetable intake. $51.5 \%$ of the anemic students were malnourished with $28.1 \%$ being under weight. In the non-anemic group $48.2 \%$ of the students were malnourished with $12.9 \%$ being under weight and $35.2 \%$ were overweight or obese (Table 4).

Peripheral smear study has revealed microcytic hypochromic blood picture in $26 \%$, normocytic 
hypochromic in $38 \%$ and normocytic normochromic in $32 \%$ of the anemic subjects.

Table 4: Dietary and social factors in the study population.

\begin{tabular}{|c|c|c|c|}
\hline Factors & $\begin{array}{l}\text { Anemic } \\
\text { subjects } \\
(n=64)\end{array}$ & $\begin{array}{l}\text { Non-anemic } \\
\text { subjects }(n= \\
85)\end{array}$ & $\begin{array}{l}P \\
\text { value }\end{array}$ \\
\hline \multicolumn{4}{|l|}{ Place of stay } \\
\hline With parents & $35(54.7 \%)$ & $39(45.9 \%)$ & \multirow[b]{2}{*}{0.184} \\
\hline $\begin{array}{l}\text { Away from } \\
\text { parents }\end{array}$ & $29(45.3 \%)$ & $46(54.1 \%)$ & \\
\hline \multicolumn{3}{|c|}{ Symptoms of anemia } & \multirow{3}{*}{0.066} \\
\hline 1-4 symptoms & $46(71.9 \%)$ & $71(83.5 \%)$ & \\
\hline $\begin{array}{l}\text { More than } 4 \\
\text { symptoms }\end{array}$ & $18(28.1 \%)$ & $14(16.5 \%)$ & \\
\hline \multicolumn{3}{|l|}{ Type of diet } & \multirow{3}{*}{0.514} \\
\hline Vegetarian & $9(14.1 \%)$ & $11(12.9 \%)$ & \\
\hline Non-vegetarian & $55(85.9 \%)$ & $74(87.1 \%)$ & \\
\hline Skips break fast & $18(28.1 \%)$ & $21(24.7 \%)$ & 0.388 \\
\hline \multicolumn{3}{|c|}{ Frequency of fried food } & \multirow{3}{*}{0.227} \\
\hline$<3$ times/week & $41(64.1 \%)$ & $65(76.5 \%)$ & \\
\hline$>3$ times/week & $23(32.8 \%)$ & $19(22.4 \%)$ & \\
\hline \multicolumn{3}{|c|}{ Frequency of fruits } & \multirow{3}{*}{0.388} \\
\hline$<3$ times/week & $46(71.9 \%)$ & $64(75.3 \%)$ & \\
\hline$>3$ times/week & $18(28.1 \%)$ & $21(24.7 \%)$ & \\
\hline \multicolumn{3}{|l|}{ Vegetables } & \multirow{3}{*}{0.116} \\
\hline$<3$ times/week & $32(50 \%)$ & $33(38.8 \%)$ & \\
\hline$>3$ times/week & $32(50 \%)$ & $52(61.2 \%)$ & \\
\hline \multicolumn{3}{|l|}{ BMI } & \multirow{5}{*}{0.068} \\
\hline $\begin{array}{l}<18.5 \\
\text { (underweight) }\end{array}$ & $18(28.1 \%)$ & $11(12.9 \%)$ & \\
\hline $\begin{array}{l}18.5-22.9 \\
\text { (normal) }\end{array}$ & $31(48.4 \%)$ & $44(51.8 \%)$ & \\
\hline $\begin{array}{l}23-24.9 \\
\text { (over weight) }\end{array}$ & $10(15.6 \%)$ & $15(17.6 \%)$ & \\
\hline$>25$ (obese) & $5(7.8 \%)$ & $15(17.6 \%)$ & \\
\hline
\end{tabular}

\section{DISCUSSION}

The prevalence of anemia among the female medical students is $43 \%$, which is a severe public health problem, according to WHO classification. ${ }^{15}$ This is similar to the prevalence of anemia in other studies, done on university students. ${ }^{16-18}$ Red cell indices and peripheral smear study, has helped us to confirm it to be iron deficiency anemia. In our study, anemia is prevalent, inspite of the students belonging to the upper-middle class or upper class, which shows that poverty alone is not responsible for the nutritional contribution, to the incidence of anemia. Other studies have also show insignificant association between prevalence of anemia and socio-economic class. ${ }^{19,20}$ Majority of our students had mild anemia which is also seen in other studies. ${ }^{18-21}$

Menorrhagia was present in $14 \%$ of the anemic subjects compared to $3.5 \%$ in non-anemic subjects. Though statistically significant, it is one of the major contributors for anemia, as established by other studies. ${ }^{18,19,22,23}$ This study has shown that students staying with parents or away from parents, are not significantly different, with respect to their anemic status but some studies have shown otherwise, with hostelers having higher incidence of anemia due to poor food quality. ${ }^{12}$ This could be because the quality of food is better, in our students hostel or the day scholars are exposed to the added stress of starting early and travelling from home every day, in addition to the burden of sharing family responsibilities along with studies.

Irrespective of their anemic status, one fourth of the study subjects regularly skip breakfast. One third of them, frequently consume fried foods and more than $50 \%$ of the students do not consume fruits and vegetables adequately in their diet. These unhealthy dietary habits are also seen in other studies done on students. ${ }^{22,24,25}$ Evidence suggests that regular breakfast intake will improve the cognitive function and have positive impact on the health of the children and young adults..$^{9,26}$ Only $13.4 \%$ of our study subjects were vegetarians, while the rest of them were non-vegetarians and more than $40 \%$ of the subjects in both the groups had anemia. This could be due to the fact that, even though claiming to be non-vegetarians, majority of them consumed mixed diet with intake of non-vegetarian food only once or twice a week. So, most of their iron supply is in the form of non heme iron, the absorption of which might be inhibited by other dietary factors.

Though the incidence of moderate and severe anemia is only $4 \%$ and $2 \%$ respectively in our study, it is still disheartening, as these are the students who have better knowledge about anemia and its consequences, compared to general population. The contributing factors are, stress of the professional course which demands long study hours, attending night postings and changes in the dietary habits in most of the students, as they enter university.

More than $50 \%$ of the anemic subjects were found to be malnourished, both under-weight and overweight, and the non-anemic students also showed similar pattern, when BMI was calculated. Even though it is said that anemia decreases with better nutritional status research has shown that, Hepcidin inhibits dietary absorption of iron leading to anemia in overweight and obese individuals. $^{27-29}$

\section{CONCLUSION}

In conclusion, frequent screening of the students for the presence of anemia and regular health checkups is mandatory in all the school going and university students, irrespective of their socio-economic class, including students undergoing professional courses. Also, nutritional programs, to help them recognize healthy nutritional habits, body nutritional requirements, quality and quantity of diet should be implemented. 


\section{ACKNOWLEDGMENTS}

Authors would like to acknowledge the support rendered by haematology laboratory, who helped in collecting the samples and in the reporting.

Funding: No funding sources Conflict of interest: None declared

Ethical approval: The study was approved by the Institutional Ethics Committee

\section{REFERENCES}

1. Shah BK, Gupta P. Weekly vs daily iron and folic acid supplementation in adolescent Nepalese girls. Arch Paediatr Adolesc Med. 2002;156:131-5.

2. World Health Organization. Iron deficiency anaemia. Assessment, prevention and control: A guide for programme managers. Geneva, Switzerland: World Health Organization;2001.

3. Stoltzfus RJ, L Mullany, RE Black. Iron deficiency anemia.In: Ezzati M, Lopez AD, Odgers A, Murray JL, editors. Comparative quantification of health risks: global and regional burden of diseases attributable to selected major risk factors. Geneva, World Health Organization;2004:163-209.

4. Webb TE, Oski FA. Behavioral status of young adolescentswith iron deficiency anaemia. J Sp Edu. 1974;8:153.

5. Shill KB, Karmakar P, Kibria MG, Das A, Rahman MA, Hossain MS et al. Prevalence of iron-deficiency anaemia among university students in Noakhali region, Bangladesh. J Health Popul Nutr. 2014;32(1):103-10.

6. Bhimrao NJ. A critical review on iron deficiency anaemia in female population of developing India. Int J Fauna Biologic Studies. 2014;3(5):116-9.

7. Ghorpade VV, Shinde PP, Madhekar NS, Pol VS. Prevalence of anaemia in female students of pharmacy college and its association with various socio-demographic variables: a study conducted in rural teaching institute, Kasegaon. Int $\mathrm{J}$ Contemp Med Res.2016;3(8):2295-7.

8. Gillespie S. Major issues in the control of iron deficiency. The micronutrient initiative. UNICEF, 1998. Available at https://www.k4health.org/sites/default/files/issues in the control of iron deficiency. Accessed $20 \mathrm{Nov}$ 2015.

9. Abalkhail B, Shawky S. Prevalence of daily breakfast intake, iron deficiency anaemia and awareness of being anaemic among Saudi school students. Int J FoodSci Nutr. 2002;53(6):519-28.

10. Kurubaran G, Sami AR, Ahmed MQ, Al-abed AA. Social and psychological factors affecting eating habits among university students in a MalaysianMedica school: a cross sectional study. Nutrition J. 2012,11:48.
11. Ayoub AI. Iron deficiency anemia in Dubai Medical College for Girls: apreliminary study. J Egypt Public Health Assoc. 1995;70(1-2):213-28.

12. Iron deficiency anaemia: assessment, prevention, and control. A guide for programme managers. Geneva, World Health Organization, 2001 (WHO/NHD/01.3).

www.who.int/nutrition/publications/.../anaemia_iron _deficiency/...3/en/ . Accessed 20 Nov 2015.

13. Consensus Group. Consensus statement for diagnosis of obesity, abdominal obesity and metabolic syndrome for asian indians and recommendations for physical activity, medical and surgical management. JAPI. 2009;57:163-70.

14. Roy RN, Saha I, Mahajan, Gupta. Textbook of preventive and social medicine. Fourth edition, Jaypee Brothers Medical Publishers (P) Ltd. New Delhi. 2013:134.

15. WHO Report, World Prevalence of Anemia 19932005. WHO Global Database on Anemia, World Health Organization,Geneva, Switzerland, 2008. http://www.WHO.Int/hinari/en/. Accessed 20 Nov 2015.

16. Khan HM, Sohail M, Ali A, Akhtar N, Khan H, Rasool F. Symptoms based evaluation of iron deficiency anemia in students of bahawalpur correlated with their eating habits. Trop J Pharm Res. 2014;13(5):769-72.

17. Al Hassan NN. The prevalence of iron deficiency anemia in a Saudi University female students. J Microscopy Ultrastructure. 2015;3(1):25-8.

18. Subramaniyan K, George M, Seshadri D, Jena A, Chandraprabha N. Prevalence of anemia among health science students of a university in South India. Int J Res Med Sci. 2016;4(10):4598-601.

19. Manjula VD, Parameshwari P, Pothen L, Sobha A. Prevalence of anemia among female undergraduate students of Government Medical College Kottayam, Kerala. Int J Med Health Sci. 2014;3(2):133-8.

20. Sultan A H. Anemia among female college students attending the University of Sharjah, UAE: prevalence and classification. J Egypt Public Health Assoc. 2007;82(3-4):261-71.

21. Waseem SM, Bano R, Ahmad N, Kumar J, Khan A. Study of haematological profile and body mass index in undergraduate medical students in Lucknow, Uttar Pradesh. IJHSR. 2015;5(6):257-62.

22. Salameh P, Jomaa L, Issa C, Farhat G, Salamé J, Zeidan $\mathrm{N}$ et al. Lebanese National Conference for Health in University Research Group. Assessment of dietary intake patterns and their correlates among university students in Lebanon. Frontiers Public Health. 2014;2:185.

23. Al-Sayes F, Gari M, Qusti S, Bagatian N, Abuzenadah A. Prevalence of iron deficiency anaemia among females at university stage. J Med Lab Diag. 2011;2(1):5-11.

24. Farthing, MC. Current eating patterns of adolescentsin the United States. Nutrition Today. 1991;26:35-9. 
25. Musaiger AO. The state of food and nutrition in theArabian Gulf Countries. World Rev Nutr Diet. 1987;54:105-73.

26. Rampersaud G, Pereira M, Girard B, Adams J, Metzl J. Breakfast habits, nutritional status, body weight, and academic performance in children and adolescents. J Am Diet Assoc. 2005;105:743-60.

27. Pandey S, Singh A. A cross sectional study of nutritional anemia among medical students in a medical college, at Bilaspur, Chattisgarh. National J Med Res. 2013;3(2):143-6.

28. Pal A, De S, Sengupta P, Maity P, Dhara PC. An investigation on prevalence of anaemia in relation to BMI and nutrient intake among adult rural population of west Bengal, India. Epidemiol Biostat Public Health. 2014;11(2):1-10.

29. Amato A, Santoro N, Calabro P, Grandone A, Swinkels DW, Perrone L et al. Effect of body mass index reduction on serum hepcidin levels and iron status in obese children. Int $J$ Obesity. 2010;34:1772-4.

Cite this article as: Kannan B, Ivan EA. Prevalence of anemia among female medical students and its correlation with menstrual abnormalities and nutritional habits. Int J Reprod Contracept Obstet Gynecol 2017;6:2241-5. 